Kholil Syu'aib, Agama dan Negara...

\title{
AGAMA DAN NEGARA \\ Reaktualisasi Pemikiran Politik Islam Munawir Sjadzali
}

\section{Kholil Syu'aib}

\begin{abstract}
Abstrak: Munawir Sjadzali salah seorang yang pernah menjabat Menteri Agama Republik Indonesia selama dua periode berturutturut (1983-1993). Beliau bukan hanya sebagai negarawan, tetapi juga seorang pemikir yang handal dalam bidang politik dan keagamaan. Pemikirannya tercermin dalam karya-karya intelektual dan kebijakan-kebijakan yang diambilnya sebagai Menteri Agama dan secara umum terekspresikan dalam agenda reaktualisasi ajaran Islam yang telah menumbuhkan makna baru politik Islam di Indonesia. Beliau lebih menekankan pentingnya substansi daripada yang formal dan legal, baik secara keagamaan maupun sosial.
\end{abstract}

Kata-kata kunci: Agama, negara dan politik Islam

Abstract: Munawir Sjadzali is one of the other which have taken hold of the Minister of Religious Affairs, Republic of Indonesia, during two period successively (1983-1993). He is not merely as statesman, but also a reliable thinker in the field of politics and religious. His opinion is drawn in intellectual masterpiece and policy taken as Minister of Religious Affairs and general expressed in agenda of reactualization of Islamic teachings have grown the new meaning of Islamic politics in Indonesia. He more emphasized importance of substance than legal and formal dimension of both religiously and socially.

Key Words: Religion, state and islamic politic

$$
\text { الملخص: منور شذالى أحد من الوزائر وهو الوزير للشئون الدينية بإندونيسيا طول الدورتين المتواليتين }
$$


Kholil Syu'aib, Agama dan Negara...

$$
\begin{aligned}
& \text { تصورت أفكاره في تصانيفه وسياسته من أجل شأنه كالوزير للشئون الدينية ووجد أكثرها فن براميج }
\end{aligned}
$$

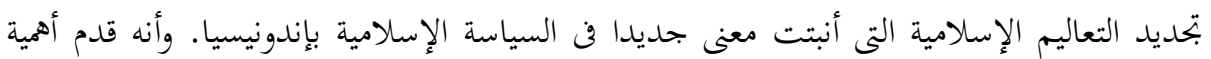

$$
\begin{aligned}
& \text { التفكير عن جوهر شئ من شرعيته وعرفيته, دينيا كان أو اجتماعيا. }
\end{aligned}
$$

Perkembangan intelektualisme Islam baru di Indonesia selama dua dekade terakhir dapat dianggap berawal dari krisis. ${ }^{1}$ Pada umumnya dipengruhi dan dibentuk oleh situasi politik Islam yang kurang menguntungkan dan akibat negatif yang ditimbulkan para pemikir dan aktivitasnya. Situasi yang tidak menggembirakan ini muncul, karena hubungan politik yang tidak harmonis antara Islam dan negara serta hasil sintesa sosiokultural dan politik antara keduanya yang tidak begitu sesuai.

Kemunculan intelektualisme Islam berupaya memberi harapan bagi penyelesaian atas masalah ketidakharmonisan hubungan antara Islam dan negara. Upaya-upaya tersebut dilakukan terutama melalui berbagai pernyataan pemikiran dan tindakan politik Islam baru yang dipandang lebih sesuai dengan kenyataan keragaman sosio-kultural dan keagamaan Indonesia. Leonard Binder menyatakan bahwa jika Islam hendak dipertahankan sebagai kekuatan sosial dan politik di Indonesia, maka harus ada orang yang memainkan peran sebagai jembatan budaya antara Islam itu dan kebudayaan nasional baru Indonesia. ${ }^{2}$

Menurut Bachtiar Efendi, hubungan antara agama dan negara di Indonesia memiliki tradisi yang amat panjang. Akarakar geneologis-nya dapat ditarik kebelakang hingga akhir abad ke-13 dan awal abad ke $14 \mathrm{M}$, ketika Islam pertamakali diperkenalkan dan disebarkan di Indonesia. Pada kenyataannya dapat dikatakan bahwa Islam sepanjang perkembanganya di Indonesia, telah menjadi bagian integral dari sejarah politik Indonesia, meskipun tidak serta merta mengandaikan bahwa 
Islam secara inheren adalah agama politik. Teori mengenai Islam politik di Indonesia yang belum jelas, secara substansi dibangun di atas landasan-landasan empirik di mana perjumpaan antara Islam dan politik di kepulauan nusantara ini berlangsung.

Situasi makro hubungan politik dan agama di Indonesia dapat dilihat dalam lima pendekatan teoritis dominan, yaitu: pendekatan dekonfessionalisasi Islam, pendekatan domestikasi Islam, pendekatan skismatik dan aliran, pendekatan trikotomi, dan pendekatan perspektif Islam kultural.

Kelima pendekatan di atas mempunyai landasan teoritis masing-masing. Pendekatan dekonfessionalisasi Islam menawarkan penjelasan yang kontruktif mengenai hubungan politik yang antagonis antara Islam dan negara. ${ }^{3}$ Pendekatan domestikasi Islam merupakan analisis mengenai implikasi-implikasi antogonis politik di atas. Sementara pendekatan skismatik dan aliran menawarkan kerangka teoritis untuk mengaitkan akar religio-kultural antogonisme tersebut dengan pola-pola pengelompokan politik di Indonesia. Kemudian pendekatan trikotomi secara konseptual mengelaborasi keragaman tingkah-laku politik umat Islam. Terakhir pendekatan perspektif Islam kultural berusaha untuk menawarkan penjelasan teoritis baru mengenai kekuatan kultural Islam di Indonesia. ${ }^{4}$

Kelima pendekatan di atas menggambarkan bahwa persoalan antara Islam dan negara di Indonesia merupakan salah satu subjek penting, walaupun telah diperdebatkan para pemikir Islam sejak hampir seabad hingga dewasa ini, tetapi belum terpecahkan secara tuntas. Menurut Munawir Sadzali, ${ }^{5}$ dalam pemikiran politik Islam terdapat tiga paradigma tentang hubungan agama dan negara. Nuansa di antara ketiga paradigma ini terletak pada konseptualisasi yang diberikan kepada kedua istilah tersebut. 6 Paradigma pertama memecahkan masalah dikotomi dengan mengajukan konsep bersatunya agama dan negara. Agama dan negara dalam hal ini tidak dapat dipisahkan 
Kholil Syu'aib, Agama dan Negara...

(integrated). Pemerintahan negara dilaksanakan atas dasar kedaulatan ilahi (devine sovereignty) yang berdasarkan wahyu, karena memang kedaulatan itu berasal dan berada di tangan Tuhan. ${ }^{7}$

Paradigma kedua memandang agama dan negara berhubungan secara simbiotik, yaitu berhubungan timbal balik dan saling memerlukan. Dalam hal ini agama memerlukan negara, karena dengan negara, agama dapat berkembang. Sebaliknya negara memerlukann agama, karena dalam agama, negara dapat berkembang dalam bimbingan etika dan moral. Paradigma ketiga bersifat sekularistik. Paradigma ini menolak baik hubungan integralistik maupun simbiotik antara agama dan negara. Sebagai gantinya, paradigma ketiga ini mengajukan pemisahan antara agama dan negara. Dalam konteks Islam paradigma sekularistik menolak pendasaran negara kepada Islam, atau paling tidak menolak determinasi Islam akan bentuk tertentu dari negara. ${ }^{8}$

Ketiga paradigma pemikiran politik dan agama di atas merupakan kesimpulan Munawir Sjadzali terhadap pemikiran politik para ulama di dunia Islam, seperti pemikiran politik alMawardi, Muhammad Rasyid Rida, Ali Abd al-Raziq, alMaududi, Muhammad Haikal, dan seterusnya. Para generasi baru intelektual Muslim di Indonesia, khususnya mereka yang perhatian utamanya adalah merumuskan kembali landasan teologis/keagamaan, tidak menemukan petunjuk yang jelas dan tegas bahwa Islam memiliki kepentingan yang kuat untuk mengatur masalah-masalah yang berkaitan dengan urusan-urusan negara. Di dalam al-Qur'an, mereka tidak melihat adanya doktrindoktrin yang secara khusus membahas mengenai masalah tersebut. Bahkan, mengingat pentingnya persoalan itu, adalah mengherankan bahwa istilah "negara" (daulah) tidak muncul dalam al-Qur'an. Lebih jauh, untuk mendukung keyakinan mereka bahwa persoalan negara Islam (daulah Islamiyah) adalah 
suatu fenomena modern, hasil perjumpaan antara dunia Islam dengan kolonialisme Barat, mereka mengargumentasikan bahwa deklarasi formal mengenai negara Islam tidak pernah benar-benar ada selama periode Islam klasik atau Islam abad pertengahan. ${ }^{9}$

Karena itu, mereka berpendapat bahwa Islam tidak mewajibkan para pemeluknya untuk membentuk sebuah negara. Melainkan berdasarkan kenyataan bahwa doktrin al-Qur'an lebih sering membicarakan masalah kemasyarakatan daripada masalah trasendental (abstrak). Mereka cenderung meyakini bahwa Islam lebih menekankan pembentukan sebuah masyarakat yang baik, yaitu masyarakat yang mencerminkan substansi pesan universal Islam (rahmatan li al-'alamin). Bagi beberapa pemikir Muslim di Indonesia, seperti Munawir Sjadzali, Nurchalis Madjid dan Bakhtiar Efendi, gagasan mengenai negara Islam atau ideologi Islam, seperti yang pernah diperjuangkan dengan gigih oleh para pemimpin dan aktivis Islam politik terdahulu, hanyalah "suatu bentuk kecenderungan apologetik". 10 Lebih khusus lagi, hal itu mencerminkan apologia (pemaksaan pemikiran) terhadap Barat seperti demokrasi liberal, sosialisme, dan kapitalisme; dan kecenderungan legalistik sebagian umat Islam dalam pemahaman mereka terhadap ajaran-ajaran Islam. ${ }^{11}$ Mereka tidak melihat cukup bukti bahwa tradisi Nabi Muhammad (sunnah) membicarakan persoalan negara atau politik secara lengkap. Dalam pandangan mereka, al-Sunnah sebagaimana al-Qur'an tidak merumuskan model terperinci mengenai bagaimana sebuah negara harus dikelola. Bahkan, menurut mereka, Nabi Muhammad sendiri tidak memberi petunjuk yang jelas bahwa apa yang telah dibangunnya di Madinah adalah sebuah lembaga politik yang dapat disebut negara. ${ }^{12}$

Munawir Sjadzali, seorang pejabat senior di Departemen Luar Negeri, yang untuk dua periode berturut-turut (1983-1993) menjabat sebagai Menteri Agama menyatakan perlunya umat Islam untuk reaktualisasi atas ajaran-ajaran Islam. Dalam konteks 
gerakan pembaharuan Islam di Indonesia, Munawir Sjadzali sebenarnya adalah tokoh yang muncul belakangan. Gagasangagasan Munawir Sjadzali mengenai reaktualisasi agama hampir sepenuhnya tidak diketahui umum sebelum penunjukannya sebagai Menteri Agama. Pengabdianya untuk jangka waktu yang panjang di Departemen Luar Negeri (1950-an hingga 1983) tidak memungkinkannya untuk terlibat aktif dalam diskursus intelektualisme Islam. Ketakterlibatannya, seperti diakuinya sendiri, telah memberinya kesempatan yang luas untuk mengamati, dan merenungkan Islam di Indonesia secara lebih objektif. ${ }^{13}$

Sudut pandang Munawi Sjadzali tentang agama dan negara terrcermin dalam tulisan-tulisan Munawir Sjadzali. Munawir Sjadzali menyimpulkan bahwa pada masa-masa awal sejarah politik Islam, tidak terdapat suatu mekanisme yang jelas mengenai suksesi kepemimpinan dan peralihan kekuasaan/wewenang. Baik Islam teoritis (doctrinal) maupun Islam empirik (sejarah) tidak menunjukkan bahwa Nabi Muhammad sudah merumuskan suatu prosedur yang mutlak dan harus diikuti dalam perkara pengelolaan negara. Satu-satunya mekanisme yang diakui adalah kewajiban untuk menerapkan prinsip musyawarah (syura). ${ }^{14}$

Menurut Munawir Sjadzali, praktek-praktek suksesi kepemimpinan khususnya pada periode awal Islam berbeda dari masa ke masa. Pada masa Nabi saw., menurut penjelasan sejarah versi Sunni,15 ada keyakinan yang umum dianut bahwa Nabi saw. tidak memilih seorang pengganti untuk posisinya sebagai pemimpin politik. Abu Bakar salah seorang sahabat terdekatnya, menjadi khalifah pertama melalui pemilihan terbatas; Umar Ibn al-Khattab khalifah kedua ditunjuk oleh Abu Bakar untuk menggantikannya; Usman Ibn 'Affan diangkat sebagai khalifah ketiga oleh sebuah panitia yang dibentuk atas perintah eksklusif 
Kholil Syu'aib, Agama dan Negara...

Umar; dan Ali Ibn Abi Talib menjadi khalifah keempat lewat suatu bentuk pemilihan yang berbeda pula. ${ }^{16}$

Para pendukung intelektual Islam baru di Indonesia menemukan bahwa baik al-Qu'an dan al-Sunnah benar-benar memberikan seperangkat prinsip etis yang relevan dengan cara mengatur negara dan mekanisme pemerintahannya. Mereka menunjukkan bahwa al-Qur'an berulangkali menyebutkan gagasan-gagasan normatif tentang musyawarah (syura), keadilan ('adl), dan egalitarianisme (musawah). Prinsip-prinsip inilah yang diterapkan dan ditunjukkan secara gamblang dalam tradisi politik Islam awal, khususnya pada masa Nabi saw. ${ }^{17}$

Menurut Ahmad Syafii Ma'arif, prinsip-prinsip politik di atas dapat dinilai sebagai titik-titik persamaan (common platform) yang memungkinkan berlangsungnya proses konvergensi sosialpolitik di antara anggota sebuah komunitas politik dengan latar belakang agama yang berbeda. ${ }^{18}$ Sementara itu, tokoh-tokoh generasi baru inteleklualisme Islam lainnya memandang Piagam Madinah sebagai dokumen politik yang memberikan model dasar bagi hubungan antara Islam dan politik serta Islam dan negara.

Arti penting Piagam Madinah itu terutama terletak pada penekanannya kepada prinsip keadilan, partisipasi, musyawarah dan egalitarianisme. Pandangan ini, setidak-tidaknya menurut Munawir Sadzali, diperkuat oleh kenyataan bahwa terlepas dari posisi mayoritas Muslim dalam komposisi masyarakat politik Madinah itu, Piagam Madinah itu sendiri tidak menyebutkan Islam sebagai agama resmi negara. Dalam bukunya yang berjudul Islam dan Tata Negara, Munawir menulis bahwa "Satu hal yang patut dicatat bahwa Piagam Madinah, yang oleh banyak pakar politik didakwakan sebagai konstitusi negara Islam yang pertama itu, tidak menyebut agama negarta" ${ }^{19}$

Pernyataan ini penting bagi Munawir, karena ia menilai bahwa penyebutan agama tertentu sebagai agama negara merupakan syarat mutlak bagi eksistensi sebuah negara. Karena 
itu, menurutnya, kenyataan bahwa Piagam Madinah tidak menyebut Islam sebagai agama negara menyiratkan bahwa Nabi Muhammad benar-benar tidak menyerukan umatnya agar mendirikan sebuah negara agama yang di dalamnya Islam menjadi satu-satunya dasar.

Berdasarkan kajian tersebut, setidak-tidaknya ada dua proposisi penting yang dapat dirumuskan. Pertama, bahwa Islam tidak memiki preferensi konseptual atau teoritis apa pun mengenai watak atau konstruk negara dan sistem pemerinthannya. Dapat dikatakan bahwa Islam tidak secara khusus mewajibkan para pemeluknya untuk mendirikan sebuah negfara, apalagi negara yang berwatak teokrasi. Kedua, Islam memiliki seperangkat nilai etis atau prinsip politik, seperti keadilan, musyawarah, dan egalitarianisme. Penerapan substansi ajaran-ajaran khusus ini, seperti yang pernah ditunjukkan dalam praktek-praktek politik Nabi Muhammad saw. yang diwajibkan dalam Islam. ${ }^{20}$

Bagi Munawir, demokrasi merupakan sistem yang sesuai dengan, atau paling tidak mendekati ajaran Islam tentang agama dan negara di Indonesia. Begitu juga sistem pemerintahan yang berdasarkan kedaulatan rakyat, di mana pemerintah bertanggung jawab kepada rakyat melalui wakil-wakil mereka di Dewan Perwakilan Rakyat merupakan sistem yang Islami.

\section{II}

\section{Agama dan Negara di Indonesia}

Dalam konteks dunia Islam, perhatian besar Munawir terhadap masalah hubungan antara Islam dan negara merupakan kewajaran. Di seluruh dunia Islam, hubungan Islam dan negara memang sudah sejak lama menjadi polemik. Ungkapan inna alIslam din wa dawlah yang populer di lingkungan kaum muslim lebih merujuk pada manifestasi Islam dalam sejarah daripada 
sebuah rumusan konsepsional yang aplicable dalam realitas. Sejak keruntuhan kolonialisme Barat pada pertengahan abad ke-20, negara-negara Islam, seperti Turki, Mesir, Sudan, Maroko, Pakistan atau Aljazair mengalami kesulitan dalam upaya membangun hubungan yang memungkinkan antara Islam dan negara dan tak jarang mengalami ketegangan bahkan permusuhan. Padahal pada saat yang sama, di sejumlah negara, Islam menduduki posisi penting, baik karena masa lalunya maupun karena Islam merupakan agama yang dianut mayoritas penduduknya. Di kalangan pengamat muncul persoalan krusial tentang bagaimana Islam sesuai atau tidak dengan sistem politik modern, dan ide tentang negara-bangsa (nation-state) merupakan unsur terpentingnya.

Dalam konteks Indonesia, hubungan antara Islam dan negara tidak hanya telah berlangsung lama. Sejak negara ini merdeka masalah tersebut telah menyulut ketegangan, permusuhan, bahkan konflik fisik antara keduanya. Dalam masamasa formatif negara ini kaum muslim tidak hanya terus menerus menyuarakan aspirasinya untuk tidak hanya menjadikan Islam sebagai dasar negara, tetapi juga menjadikan sistem politik Islam sebagai panduan dalam mengatur negara. Meski pada akhirnya terjadi kompromi-kompromi, aspirasi demikian itu tak kunjung padam; setiap ada kesempatan dan peluang sekecil apa pun aspirasi demikian kembali muncul ke permukaan.

Paling sedikit terdapat dua kesempatan dan peluang resmi yang digunakan kaum muslim Indonesia untuk mewujudkan aspirasi politiknya. Pertama, pada saat berlangsungnya diskusi mengenai dasar negara pada 1945. Pada kesempatan ini wakilwakil Islam mengusulkan agar Islam dijadikan ideologi atau agama negara. Kedua, pada dekade 1950-an dalam sidang-sidang Konstituante yang memberi peluang pada setiap kelompok untuk mendiskusikan kembali konstruk ideologi dan undang-undang dasar. Pada kesempatan ini, melalui tokoh-tokoh Masyumi, 
Kholil Syu'aib, Agama dan Negara...

aspirasi ideologi Islam kembali muncul. Bahkan jika dibandingkan dengan yang terjadi pada kesempatan pertama, kesempatan kedua ini menyajikan perdebatan lebih luas dan mendalam mengenai pentingnya ideologi Islam dan konsepsi sistem politik Islam dalam negara Indonesia. Akan tetapi, di samping peluang-peluang resmi tadi, kaum muslim juga terusmenerus menyuarakan aspirasi Islam ideologis dalam berbagai forum dan kesempatan. ${ }^{21}$

Kerasnya sikap kaum muslim dalam memperjuangkan aspirasi politiknya, ternyata membawa implikasi negatif- jika tidak boleh dikatakan merugikan masyarakat Islam Indonesia, baik pada masa Orde Lama maupun Orde Baru. Di kalangan pemerintah tidak hanya muncul kecurigaan terhadap kaum muslim, tetapi mereka juga dipandang sebagai kelompok yang tidak sepenuhnya bersedia menerima Pancasila sebagai ideologi negara.

Situasi demikian pada gilirannya menimbulkan respons balik. Tidak sedikit pemikir dan aktivis politik Islam yang memandang negara dengan curiga. Terlepas dari kesediaan negara untuk memberikan berbagai fasilitas dan bantuan bagi masyarakat Islam dalam menjalankan arti penting Islam secara politik dan menerapkan kebijakan ganda terhadap Islam. Sementara membiarkan atau bahkan mendorong dimensi ritual Islam untuk tumbuh, negara tidak memberi kesempatan bagi politik Islam untuk berkembang. ${ }^{22}$ Dalam kaitan ini dapat dikatakan bahwa dalam negara yang mayoritas penduduknya beragama Islam berkembang rasa saling curiga antara kelompok Islam dan negara.

Berkembangnya rasa saling curiga dan permusuhan politik antara Islam dan negara memicu munculnya gerakan intelektualisme Islam baru. Gerakan yang muncul pada 1970-an ini secara umum bertujuan meredusir jika tidak bisa menghilangkan sama sekali- rasa saling curiga antara Islam dan 
negara yang dalam pandangan mereka tidak hanya merugikan masyarakat Islam Indonesia, tetapi juga tidak kondusif bagi perkembangan bangsa karena menyiratkan adanya perpecahan antar unsur dalam negara. Gerakan ini bermaksud menciptakan format baru politik Islam yang dipandang sesuai dengan konstruk ideologis negara kebangsaan Indonesia. Gerakan ini bekerja pada berbagai tingkat. Pertama, mereka bekerja pada tingkat pemikiran, yaitu merumuskan basis teologis yang sejalan dengan pandangan mereka mengenai hubungan Islam dan negara. Kedua, mereka bekerja pada tataran gerakan sosial, yaitu melakukan aksi-aksi sosial yang bertujuan memberdayakan dan mentransformasikan masyarakat Islam Indonesia sehingga dari sosial-ekonomi sejahtera dan dari pemikiran tidak lagi terikat dan memperjuangkan aspirasi Islam sebagai ideologi. Ketiga, mereka juga bekerja di birokrasi pemerintahan.

Meskipun antara yang satu dengan lainnya tidak selalu memiliki hubungan, antara ketiganya terdapat kesamaan pandangan mengenai hubungan antara Islam dan negara. Pada prinsipnya mereka meneguhkan adanya perspektif baru yang berguna untuk melihat hubungan Islam dan negara. Pertama, dalam pandangan mereka tidak ada bukti yang jelas bahwa alQur'an dan Sunnah mengharuskan komunitas muslim untuk mendirikan sebuah negara Islam. Menurut pengamatan mereka, pengalaman politik Nabi Muhammad tidak meliputi proklamasi berdirinya sebuah negara Islam. Oleh karena itu, mereka menolak agenda politik dan aktivis politik Islam terdahulu yang seakanakan menuntut berdirinya sebuah negara Islam atau negara yang berdasarkan ideologi Islam.

Kedua, mereka menyadari bahwa Islam mengandung prinsip- prinsip atau etika sosial-politik. Meski demikian, mereka berpendapat bahwa bahwa Islam bukan ideologi, bahkan mereka tegaskan bahwa tidak ada ideologi Islam. Lebih dari itu, mereka 
berpendapat bahwa mengideologikan Islam dapat dipandang sebagai tindakan meredusir posisi Islam.

Ketiga, karena Islam dipandang sebagai doktrin yang abadi dan universal, pemahaman muslim terhadap seluruh doktrin Islam tidak boleh dibatasi pada dataran yang bersifat legal-formal. Mereka menganjurkan agar pemahaman muslim yang menyeluruh terhadap doktrin Islam hendaknya didasarkan atas penafsiran yang menyeluruh yang sesuai dengan tuntutan zaman. Pandangan seperti ini pada gilirannya mengharuskan adanya transformasi Islam terhadap prinsip-prinsip dan praktik kontemporer.

Keempat, mereka sepakat bahwa hanya Allah yang memiliki kebenaran mutlak. Dengan demikian adalah mustahil menagkap realitas absolut Islam. Pandangan kaum muslim atas doktrin Islam, dengan demikian, bersifat relatif dan karenanya bisa berubah. Karena sifat Islam yang polyiinterpretable dan kenyataan bahwa Islam tidak mengakui adanya struktur kependetaan dalam Islam, maka tak boleh ada individu-individu yang mengklaim pemahamannya tentang Islam lebih otoritatif dibandingkan yang lain. Oleh karena itu, sudah semestinya kaum muslim bersikap toleran dalam beragama, baik internal maupun eksternal. ${ }^{23}$

Dari perspektif intelektualisme baru ini, perjuangan politik Islam harus diwujudkan dalam dataran substansi daripada dataran logal-formal, mereka lebih mementingkan isi daripada simbol. Mengesampingkan fokus perhatian terhadap struktur dan berusaha mengakhiri hubungan antagonistik antara Islam dan negara, mereka tidak melihat adanya suatu alasan yang kuat untuk tidak menerima konstruk negara-bangsa dengan Pancasila sebagai dasarnya. Dalam pandangan mereka, kaum muslim hendaknya membangun komitmen kepada nilai-nilai Islam dan bukan pada institusi atau organisasi yang memakai simbol Islamtermasuk di dalamnya partai Islam. 
Menurut Munawir Sjadzali, dapat dimengerti bila pada masa dasawarsa lima puluhan umat Islam menjadi curiga dengan penafsiran yang simpang-siur tentang Pancasila, khususnya penafsiran dari kelompok sekuler. Tetapi, sejak lahirnya Orde Baru penafsiran baku tentang Pancasila telah menjadi jelas. Dalam banyak kesempatan, antara lain sewaktu menyampaikan pidato tahunannya di muka DPR-RI, pada tanggal 16 Agustus 1986, Presiden Soeharto menegaskan bahwa negara Republik Indonesia yang berdasarkan Pancasila bukanlah negara agama, tetapi bukan pula negara sekuler. ${ }^{24}$

Tafsiran tersebut diikuti oleh kebijaksanaan-kebijaksanaan politik yang memberikan tempat dan peranan yang terhormat kepada agama. Kekhawatiran terhadap kemungkinan disahkannya undang-undang atau peraturan perundangundangan yang bertentangan dengan ajaran atau hukum Islam dapat diatasi dengan berbagai cara, di antaranya dengan peningkatan kesadaran umat Islam, baik yang duduk dalam lembaga-lembaga legislative dan eksekutif maupun yang berada di luar; mengembangkan peranan Majelis Ulama Indonesia (MUI) dengan Komisi Fatwanya. Munawir Sjadzali berkata:

Sejarah negara kita sejak proklamasi kemerdekaan tahun 1945 rasanya belum pernah diundangkan suatu undang-undang yang jelas-jelas melanggar ketentuan Islam atau yang tegas-tegas secara diametrical berlawanan dengan ajaran atau hukum Islam... Rasa tanggung jawabpara anggota DPR-RI yang beragama Islam terhadap ajaran agama mereka pada umumnya sangat tinggi, hal mana insya Allah merupakan suatu jaminan melekat tentang tidak akan terjadinya apa yang dikhawatirkan tersebut. ${ }^{25}$

III 
Kholil Syu'aib, Agama dan Negara...

\section{Asas Tunggal Pancasila}

Dalam konteks kemunculan intelektualisme baru Islam dan resistensi kalangan Islam ideologis terhadapnya, pemerintah mengintrodusir gagasan untuk menjadikan Pancasila sebagai satu-satunya asas dalam kehidupan bermasyarakat, berbangsa dan bernegara. Gagasan Pancasila sebagai asas tunggal ini dilontarkan Presiden Soeharto dalam Rapim ABRI di Pekanbaru, pada 27 Maret 1980. Selanjutnya ditegaskan kembali dalam pidato tanpa teks pada acara ulang tahun Kopassandha (Korp Pasukan Sandi Yudha; kini Kopassus) di Cijantung pada 16 April 1980. Pidato Presiden ini pada gilirannya menimbulkan reaksi dari para pemimpin Islam dan sejumlah pensiunan perwira militer yang kemudian membentuk kelompok yang disebut dengan "Petisi 50". Dalam "Pernyataan Keprihatinan" yang disampaikan ke DPR-RI pada 13 Mei 1980, "Petisi 50" antara lain menuduh Presiden Soeharto telah menggunakan Pancasila sebagai senjata untuk melumpuhkan lawan-lawan politiknya, padahal oleh para pendiri republik ini (founding fathers) Pancasila dimaksudkan sebagai pemersatu bangsa. ${ }^{26}$

Dalam konteks perkembangan politik Indonesia Orde Baru, keputusan menjadikan Pancasila sebagai asas tunggal ini merupakan kelanjutan dari keputusan politik pemerintah pada masa sebelumnya yang secara umum tidak mengizinkan berkembangnya Islam sebagai kekuatan politik riil. Pada awal Orde Baru pemerintah tidak hanya menolak rehabilitasi Masyumi, tetapi juga melarang para tokohnya untuk aktif di Parmusi, partai Islam yang dipandang sebagai pengganti Masyumi. Pada perkembangan lebih lanjut, di samping menerapkan kebijakan floating mass, pemerintah juga memfungsikan partai-partai politik menjadi tiga kekuatan politik, Partai Persatuan Pembangunan (PPP), Golongan Karya (Golkar), dan Partai Demokrasi Perjuangan (PDI). PPP merupakan fusi dari partai-partai Islam, Golkar merupakan kekuatan profesional yang terutama terdiri 
Kholil Syu'aib, Agama dan Negara...

dari pegawai negeri sipil, dan PDI merupakan fusi dari partaipartai nasionalis, Katolik, dan Kristen. ${ }^{27}$

Motif pemerintah menjadikan Pancasila sebagai asas tunggal adalah semata-mata untuk menjaga Pancasila sebagai dasar dan ideologi negara dan mensosialisasikannya dalam kehidupan kebangsaan. Sepanjang sejarah, Pancasila sebagai dasar dan ideologi negara, memang selalu mendapat tantangan dari berbagai pihak- dalam perspektif pemerintah tantangan ini bersumber dari kalangan "ekstrim kiri" dan "ekstrim kanan". Meskipun tantangan-tantangan tersebut dapat diatasi, ia dapat dibaca sebagai petunjuk masih adanya kelompok-kelompok dalam masyarakat yang belum bersedia menerima Pancasila sebagai ideologi negara. ${ }^{28}$

Namun, secara langsung, seperti terungkap dalam Pidato Presiden, keputusan menjadikan Pancasila sebagai asas tunggal dilatarbelakangi sejumlah peristiwa. Antara lain peristiwa walkout PPP dari Sidang Umum MPR 1978 sebagai reaksi terhadap disahkannya P4 (Pedoman Penghayatan dan Pengamalan Pancasila). Partai ini juga melakukan walk-out dalam sidangsidang DPR pada 1980. Karena dua kali melakukan walk-out pemerintah memandang bahwa PPP yang merupakan hasil fusi partai-partai berhaluan Islam belum sepenuhnya menerima Pancasila sebagai ideologi negara. Hal lain yang turut mendorong pemerintah menjadikan Pancasila sebagai asas tunggal adalah peristiwa yang terjadi sepanjang kampanye Pemilu 1982. Dalam masa kampanye, terjadi persaingan ideologis yang tak jarang disertai dengan kekerasan yang menimbulkan korban jiwa antara para pendukung PPP dan Golkar. Tidak hanya itu, persaingan itu bahkan muncul dalam level agama. Isu-isu keagamaan seperti mengkafirkan kelompok lain dan sebagainya mewarnai kampanye-kampanye pada masa ini. Ketua Umum Golkar waktu itu, Amir Moertono, sampai merasa perlu menegaskan bahwa 
Pemilu adalah semata-mata masalah politik, karena itu tidak bisa dijadikan ukuran ketaatan orang dalam beragama. ${ }^{29}$

Melalui Ketetapan MPR-RI No II Tahun 1983, Pancasila ditetapkan sebagai satu-satunya asas dalam kehidupan berbangsa dan bernegara. Sebagai kelanjutan dari ketetapan MPR ini, pemerintah secara berturut-turtut mengajukan lima RUU bidang politik yang terdiri RUU tentang Pemilihan Umum; RUU bidang politik dan Golongan Karya; RUU tentang Referendum; dan RUU tentang Organisasi Kemasyarakatan (Ormas). Kelima RUU ini telah mengundang munculnya reaksi dari berbagai kalangan. Namun, dari kelima RUU tersebut dua di antaranya, yaitu RUU tentang Partai Politik dan Golongan Karya dan RUU tentang Ormas, merupakan RUU paling menyita perhatian. RUU pertama akan menghilangkan asas ciri dari setiap parpol sehingga nantinya akan menjadi partai terbuka, termasuk PPP dan PDI. Sedangkan RUU kedua, intinya mengharuskan setiap Ormas, termasuk yang berhaluan keagamaan, untuk menjadikan Pancasila sebagai asasnya.

Untuk partai politik, masalah Pancasila sebagai asas tunggal ini tidak mendapat ganjalan berarti, meskipun dalam kasus PPP masalah ini melewati perdebatan alot. Namun untuk Ormas, termasuk ormas-ormas Islam, pelaksanaan Pancasila sebagai satu-satunya asas tidak hanya melewati proses yang alot dan polemik keras, bahkan sampai menimbulkan korban jiwa. Reaksi paling keras, dapat diduga, muncul dari kalangan aktivis dan pemikir Islam lama yang masih memperjuangkan aspirasi politik Islam secara formalistik. Sementara itu, dari lingkungan ormas-ormas Islam seperti NU, Muhammadiyah, Majelis Ulama Indonesia (MUI), Himpunan Mahasiswa Islam (HMI), dan sebagainya bersikap menunggu sambil mempelajari maksud pemerintah. ${ }^{30}$

Dalam situasi sosial-politik seperti inilah Munawir Sjadzali diangkat sebagai Menteri Agama. Di sini Munawir segera 
dihadapkan kepada kelompok-kelompok Islam lama yang masih memperjuangkan ideologi Islam dan secara a priori menolak Pancasila sebagai asas tunggal; kalangan intelektualisme baru yang tidak lagi mempejuangkan ideologi Islam dalam bentuk partai Islam atau negara Islam, sebaliknya malah bersemboyan Islam yes, Partai Islam no!; dan kalangan ormas-ormas Islam yang masih bersikap menunggu.

Perkembangan-perkembangan yang terjadi di kalangan umat Islam Indonesia tersebut tidak terlepas dari pengamatan Munawir, meskipun secara formal ia bekerja di Departemen Luar Negeri. Bahkan karena tidak terlibat langsung dalam organisasiorganisasi Islam, Munawir mengakui dapat sepenuhnya mendudukkan diri sebagai pengamat. Bahkan dengan peristiwa ini, ia dapat berfikir dan menganalisis secara "objektif" perkembangan-perkembangan yang terjadi di kalangan umat Islam Indonesia.

Tugas pokok pertama Munawir sebagai Menteri Agama adalah mensosialisasikan dan menuntaskan Ketetapan MPR RI No II Tahun 1983 tentang Pancasila sebagai satu-satunya asas bagi seluruh organisasi kemasyarakatan yang berhaluan keagamaan, termasuk Islam. ${ }^{31}$ Tugas ini jelas tidak ringan. Bukan saja karena masalah ini, seperti telah disebutkan, telah menimbulkan kontroversi di kalangan agamawan, tetapi reaksi yang muncul di kalangan umat Islam terutama dari kelompok Islam ideologis juga demikian keras. Lebih dari itu, organisasi-organisasi kemasyarakatan Islam yang besar seperti NU dan Muhammadiyah juga tidak bersedia menerima begitu saja kebijakan ini. Berhadapan dengan kondisi ini Munawir mengajak tokoh-tokoh dari agama-agama yang ada di Indonesia untuk mencari jalan bagaimana menerapkan Ketetapan MPR itu tanpa mengurangi keutuhan akidah dan iman.

Dalam menyelesaikan tugas berat ini, Munawir bertitik tolak pada prinsip bahwa pemerintah tidak ada maksud sama 
Kholil Syu'aib, Agama dan Negara...

sekali untuk menggantikan agama dengan Pancasila atau mengagamakan Pancasila. ${ }^{32}$ Motif pemerintah adalah agar masalah asas negara ini sudah dapat diselesaikan secara tuntas sebelum republik ini "diserahterimakan" kepada generasi pasca 45. Dikhawatirkan jika masalah mendasar ini tidak diselesaikan, maka bukan tidak mungkin akan muncul krisis-krisis nasional seperti yang terjadi di masa lalu. Jika ini terjadi, maka usaha mengembalikan kesatuan bangsa ini merupakan pekerjaan yang sulit, lebih sulit dibandingkan dengan sebelumnya. Langkah pertama Munawir adalah memanfaatkan forum Wadah Musyawarah Umat Beragama yang mempresentasikan majelismajelis agama seperti MUI, DGI, MAWI, Parisada Hindhu Dharma dan Walubi. ${ }^{33}$

Pada Desember 1983, Munawir dalam kapasitasnya sebagai Menteri Agama meminta forum tersebut untuk menyelenggarakan pertemuan. Pokok-pokok pikiran dalam pertemuan ini selanjutnya dikirimkan kepada pemerintah dalam hal ini Departemen Dalam Negeri sebagai masukan penyusunan RUU Keormasan. Meskipun demikian, bukan berarti masalah Pancasila sebagai asas tunggal ini telah selesai. Sebagian besar organisasi kemasyarakatan masih mengajukan keberatankeberatan. Dari pihak MAWI dan DGI keberatan karena mereka merasa bukan organisasi massa, juga merupakan bagian dari organisasi yang bertaraf internasional. Meskipun pada 1986 mereka bersedia menerima Pancasila, proses yang dilewati cukup rumit. Padahal Presiden telah menyatakan akan menjamin bahwa "Pancasila tidak akan menggantikan agama; adalah mustahil Pancasila menggantikan agama. Pancasila juga disejajarkan dengan agama, dan adalah mustahil menyejajarkan Pancasila dengan agama. ${ }^{34}$

Selain menggunakan Forum Wadah Musyawarah Umat Beragama untuk menyamakan persepsi di kalangan agamawan tentang penerapan Pancasila sebagai asas organisasi, Munawir 
Kholil Syu'aib, Agama dan Negara...

juga menugaskan jajaran staf ahli Menteri Agama untuk berdialog dengan para pemimpin ormas Islam. Dialog ini dimaksudkan untuk menjaring pendapat dan aspirasi mereka berkaitan dengan keputusan politik pemerintah tersebut. Sehubungan dengan ini, Dr. Anwar Haryono, salah seorang tokoh Masyumi di masa lalu dan eksponen Dewan Dakwah Islamiyah Indonesia (DDII) berkomentar, "sungguh surprise bahwa pemerintah sekarang memperlihatkan sikap akomodatif terhadap aspirasi umat, ini jelas berbeda dengan masa Demokrasi Terpimpin dahulu". ${ }^{35}$

Dalam pandangan Munawir pribadi, keputusan menjadikan Pancasila sebagai asas tunggal ini bukan hanya tepat, tetapi juga penting untuk menjamin integrasi nasional di masa depan. Sebaliknya, tuntutan sebagiann kelompok Islam untuk menjadikan Islam sebagai ideologi negara atau bahkan mendirikan negara Islam dalam konteks Indonesia adalah tidak tepat. Ide tersebut secara konseptual tidak ditemukan rujukannya dalam al-Qur'an dan hadis yang merupakan sumber-sumber pokok Islam. Tidak ada kewajiban bagi kaum muslim untuk menjadikan Islam sebagai ideologi negara, apalagi kewajiban mendirikan negara Islam. Al-Qur'an dan hadis hanya memberikan prinsip-prinsip dasar penyelenggaraan dan pengaturan negara, seperti prinsip musyawarah (syura), keadilan (al-adl), dan persamaan (al-musawah). ${ }^{36}$ Apalagi pemerintah sendiri tidak ada maksud untuk menggantikan agama dengan Pancasila atau pun mengagamakan Pancasila. Jika masih ada kelompokkelompok yang menentang Pancasila sebagai asas tunggal, penolakan ini hanya didasarkan pada a priori saja. ${ }^{37}$ Sebagai Menteri Agama, Munawir juga mengajak umat Islam untuk menerima negara Indonesia berdasarkan Pancasila, sebagai sasaran terakhir aspirasi politik, bukan sasaran sementara untuk mencapai sasaran-sasaran lainnya. ${ }^{38}$

Meskipun Munawir telah mengadakan dialog dengan para tokoh agama, reaksi keras dari pemimpin dan aktivis Islam tetap 
Kholil Syu'aib, Agama dan Negara...

tak terhindarkan. Deliar Noer, salah seorang tokoh intelektual Islam yang cukup berpengaruh, mengatakan bahwa pandanganpandangan Munawir tidak merefleksikan intelektualitasnya, tetapi lebih merefleksikan dirinya sebagai politisi yang berperan sebagai juru bicara pemerintah Orde Baru. Deliar mengakui bahwa di bawah Orde Baru kehidupan keagamaan mengalami perkembangan menggembirakan. Akan tetapi, harus juga dicatat bahwa pembangunan yang dicanangkan dibarengin dengan semakin besarnya kesenjangan antara "yang kaya" dan "yang miskin", Kristenisasi, sekularisme, konsumerisme, kejahatan dan prostitusi. ${ }^{39}$

Penolakan Deliar Noer terhadap Pancasila sebagai asas tunggal didasarkan pada dua alasan pokok. Pertama, Pancasila sebagai asas tunggal selain bertendensi pada terbentuknya partai tunggal, juga akan menghalangi kebebasan masyarakat dalam menyampaikan aspirasinya- yang merupakan ciri utama masyarakat yang demokratis. Kedua, adalah keliru melihat konflik yang terjadi pada masa kampanye merupakan akibat perbedaan ideologis di kalangan partai-partai peserta Pemilu. Deliar merujuk Pemilu 1955 yang berlangsung tanpa konflik sebagai bukti. Padahal partai-partai peserta Pemilu waktu itu mendasarkan diri pada ideologi yang berbeda-beda. ${ }^{40}$

Di tangan kelompok-kelompok lain, kritisisme dari para pemimpin dan aktivis Islam ini selanjutnya berkembang menjadi penolakan total. Menurut penjelasan resmi pemerintah, penolakan ini memuncak pada peristiwa kekerasan antara sekelompok umat Islam dan aparat pemerintah di Jakarta pada 1984, yang populer dengan "Peristiwa Tanjung Priok". Peristiwa yang menimbulkan jatuhnya korban jiwa ini dalam pandangan pemerintah, akibat sikap militan sebagian kaum muslim dalam menyikapi Pancasila sebagai asas tunggal. Para pemimpin kelompok militan bahkan menyatakan siap menjadi martir dalam mempertahan "dasar Islam". Selanjutnya, peristiwa kekerasan ini diikuti peledakan 
Kholil Syu'aib, Agama dan Negara...

BCA (Bank Central Asia) di Jakarta, Candi Borobudur di Jawa Tengah, dan Kompleks Marinir Cilandak. ${ }^{41}$

Rentetan peristiwa ini oleh Munawir dipandang sebagai bentuk ekstrim penolakan aktivis dan pemikir Islam lama terhadap keputusan menjadikan Pancasila sebagai asas tunggal. Sementara ormas-ormas Islam yang besar dan berpengaruh, seperti NU dan Muhammadiyah, tidak menunjukkan sikap mereka. Sebaliknya, ormas-ormas ini malah aktif mencari informasi yang akurat dari pemerintah tentang maksud dibalik keputusan menjadikan Pancasila sebagai asas organisasiorganisasi sosial kemasyarakatan. Akhirnya seluruh ormas Islam bersedia menerima Pancasila sebagai asas organisasinya.

Ormas Islam pertama yang menerima Pancasila sebagai satu-satunya asas adalah NU. Penerimaan ini terjadi dalam Musyawarah Alim Ulama NU yang berlangsung Desember 1983. Setelah melalui perdebatan keras dan adu argumentasi, NU menerima Pancasila sebagai asas organisasi dengan pengertian tetap utuhnya akidah Islamiyah Ahl al-Sunnah wa al-Jamaah. ${ }^{42}$ Keputusan-keputusan ini akhirnya dikukuhkan dalam Muktamar NU di Situbondo pada Desember 1984. ${ }^{43}$ Sedangkan Muhammadiyah, meskipun tidak secepat NU dalam menerima Pancasila sebagai asas organisasinya, sejak semula tidak a priori terhadap keputusan pemerintah tersebut. Muhammadiyah terlebih dahulu ingin mencari kejelasan di mana tempat Islam setelah menerima Pancasila sebagai satu-satunya asas dalam organisasi. Upaya Muhammadiyah ini dilakukan melalui segala tingkat; mulai dari pertemuan menteri-menteri bersangkutan, khususnya Mendagri dan Menag, sampai pertemuan dengan pimpinan DPR dan fraksi-fraksi. Dengan proses demikian, tidak heran jika penerimaan Pancasila sebagai satu-satunya asas organisasi Muhammdiyah pada Muktamar ke-41 di Solo berlangsung lancar-tanpa perdebatan. ${ }^{44}$ 
Kholil Syu'aib, Agama dan Negara...

Munawir menyimpulkan bahwa pemerintah Orde Baru ternyata sangat memperhatikan pendapat masyarakat. Hal ini tampak dalam perbedaan antara RUU Keormasan dan UU No. 8. Tahun 1985 di mana banyak sekali penyempurnaanpenyempurnaan mendasar. Munawir menyebut pola yang dipakai oleh NU sebagai contoh. Menurut ketentuan, agar tidak terjadi asas ganda maka tidak dibenarkan menggunakan kata-kata dasar, alas, dan sendi. Tidak dibenarkan menggunakan rumusan bahwa organisasi bersangkutan berasaskan Pancasila dan bersendikan Islam. Menghadapi masalah ini, NU mengusulkan rumusan "berasaskan Pancasila dan beraqidah Islam". Rumusan tersebut diterima pemerintah dan selanjutnya menjadi pola bagi organisasi-organisasi lain. Selain itu, ia juga mendapat pengetahuan bahwa ternyata demokrasi Pancasila mampu menyalurkan aspirasi rakyat. Dengan kesimpulan demikian, tidak heran jika Munawir mempertanyakan kelompok atau individu yang tidak bersedia menerima Pancasila sebagai asas tunggal dengan pertanyaan: "Jika masih ada kelompok-kelompok Islam yang masih menolak Pancasila sebagai asas tunggal, mereka mewakili siapa?" 45

Keberhasilan Munawir menuntaskan masalah Pancasila sebagai asas tunggal bagi ormas-ormas berhaluan keagamaan selanjutnya menjadi "batu loncatan" bagi suksesnya programprogram Munawir yang lebih belakangan. Di antaranya yang menonjol adalah pembenahan IAIN dan lembaga-lembaga pendidikan Islam di bawahnya; restrukturisasi Peradilan Agama dan Kodifikasi Hukum Islam; dan reaktualisasi Islam. Harus diakui bahwa kesediaan ormas-ormas Islam untuk menerima Pancasila sebagai asas tunggal telah mengubah pandangan pemerintah tentang umat Islam yang selama ini dicitrakan sebagai "ekstrim kanan" di mana pada masa ini kepentingan-kepentingan umat Islam diakomodasi oleh pemerintah. Memandang ke belakang, Munawir mengatakan bahwa kepentingan-kepentingan 
Kholil Syu'aib, Agama dan Negara...

kaum muslim justru terpenuhi dengan absennya partai-partai Islam. ${ }^{46}$

Munawir sebagai intelektual dengan konsisten menolak konsep negara Islam tidak hanya menemukan momentum untuk merealisasikan prinsipnya, tetapi memiliki persesuaian yang prinsipil dengan keputusan yang sedang disosialisasikan pemerintah Orde Baru. Ia menegaskan:

Kita bangsa Indonesia khususnya umat Islam, patut bersyukur kepada Allah S.W.T. bahwa para pendahulu kita, para pendiri Republik Indonesia telah merumuskan Pancasila untuk dijadikan ideology negara. Marilah kita perbandingkan lima sila dari Pancasila dengan prinsip-prinsip dan tata nilai yang telah diamanatkan oleh Al-Qur`an. Kita akan melihat adanya persamaan, termasuk juga semangatnya... hendaknya kita umat Islam Indonesia menerima negara Republik Indonesia yang berdasarkan Pancasila ini sebagai sasaran akhir dari aspirasi politik kita, dan bukan sekedar sasaran antara atau batu loncatan ke arah sasaran-sasaran yang lain. ${ }^{47}$

Pernyataan Munawir Sjadzali menggambarkan kondisi bangsa Indonesia yang sangat majemuk, meskipun umat Islam antara delapan puluh persen rakyat Indonesia, tetapi bangsa Indonesia yang hendak dibangun meliputi seluruh bekas eilayah Hindia Belanda, termasuk daerah-daerah yang sebagian besar penduduknya beragama bukan Islam, khususnya di Indonesia Bagian Timur. Pancasila dengan Ketuhanan Yang Maha Esa sebagai sila pertama merupakan dasar negara yang paling dapat diterima oleh seluruh rakyat Indonesia yang menganut berbagai agama.

\section{IV}

Menteri Agama yang diduduki Munawir Sjazdali selama dua periode berturut-turut (1983-1993) telah mengeluarkan 
Kholil Syu'aib, Agama dan Negara...

kebijakan berkenaan dengan kehidupan keagamaan dan lembagalembaga keagamaan. Secara umum kebijakan-kebijakan itu berada di bawah semangat Munawir Sjadzali untuk merumuskan hubungan yang harmonis antara Islam dan negara. Rumusan yang diajukan memiliki afinitas dengan mainstream kebijakan negara yang ingin meneguhkan Pancasila sebagai satu-satunya asas bagi seluruh organisasi politik dan organisasi sosial kemasyarakatan, termasuk yang berhaluan agama. Konsepkonsep yang dibawa Munawir Sjadzali mendapat dukungan sepenuhnya dari negara.

Pemerintah Orde Baru tidak hanya mendorong kaum muslim untuk menjalankan agama dengan mendirikan lembagalembaga bantuan, tetapi melaksanakan perintah-perintah ritual agama dengan terang-terangan. Gairah kehidupan keagamaan tidak hanya mengalami kebangkitan, tetapi mendapatkan fasilitas untuk berkembang. Tercatat pada 1982 pemerintah mendirikan Yayasan Amal Bakti Muslim Pancasila, yang diketuai oleh Presiden Soeharto.

Pemikiran politik dan keagamaan Munawir Sjadzali tercermin dalam karya-karya intelektual dan kebijakan-kebijakan yang diambilnya sebagai Menteri Agama dan secara umum terekspresikan dalam agenda reaktualisasi ajaran Islam telah menumbuhkan makna baru politik Islam di Indonesia. Munawir Sjadzali lebih menekankan pentingnya substansi daripada yang formal dan legal, baik secara keagamaan maupun sosial. Dengan konsepsi semacam ini, sejalan dengan mobilitas sosial ekonomi umat, aspirasi umat Islam tidak lagi didasarkan atas simbolisme ideologis yang formalistik dan legalistik.

\section{DAFTAR KEPUSTAKAAN}

Ahmad Syafii Maarif, "Piagam Madinah dan Konfergensi Sosial" apendiks dalam Islam dan Politik Pada Masa Demokrasi Terpimpin (1959-1965, (Yogyakarta: IAIN Sunan Kalijaga Press, 1988 
Kholil Syu'aib, Agama dan Negara...

Azyumardi Azra, dan Saiful Umam, (ed.), Menteri-Menteri Agama RI Biografi Sosial-Politik, (Jakarta: PPIM, 1998

Bahtiar Effendi, "Islam and the State in Indonesia: Munawir Sjadzali and the Development of New Theological Underpinning of Political Islam," Studia Islamika, Volume 2, Number 2, 1995

, Islam dan Negara: Transformasi dan praktik Politik Islam di Indonesia, (Jakarta: Paramadina, 1998

C.A.O. Van Nieuwenhuijze, "Islam and National Self-Realization in Indonesia," dalam Cross-Cultural Studies, (The Hague: Monton and Co., 1963

Deliar Noer, Islam dan Pemikiran Politik: Bahasan Kitab Islam dan Tata Negara oleh H. Munawir Sjadzali, MA (Jakarta: LIPPM, 1990

Deliar Noer, Islam, Pancasila, dan Asas Tunggal (Jakarta: Yayasan Perkhidmatan, 1984

Einar Martahan Sitompul, NU dan Pancasila (Jakarta: Sinar Harapan, 1989

Faisal Ismail, "Pancasila as a Sole Basis for All Political Parties and for All Mass Organizations: An Account of Muslims Responses, "Studia Islamika, Volume 3, Number 4, 1996

Harry J. Benda, The Cresent and the Rising Sun: Indonesian Islamunder the Japanese Occupation 1942-1945 (The Hague and Bandung: W. van Hoeve Ltd., 1958

Kontekstualisasi Ajaran Islam: 70 Tahun Prof. Dr. H. Munawir Sjadzali, MA, (Jakarta: Yayasan Paramadina, 1995

Leonard Binder, "Islamic Tradition and Politics: The Kijaji and the Alim", A Commentary to Clifford Geertz's "The Javanese Kijaji: The Changing Role of A Cultural Broker", Comparative Studies in Society and History, Vol. 2, Oktober 1959-July 1960 
Kholil Syu'aib, Agama dan Negara...

Lukman Harun, Muhammadiyah dan Asas Pancasila (Jakarta: Pustaka Panjimas, 1986

Muhammad Din Syamsuddin, Etika Agama dalam Membangun Masyarakat Madani, (Jakarta: Logos, 2000

Munawir Sjadzali, Islam dan Tata Negara, (Jakarta: UI Press, 1993

Munawir Sjadzali, Islam Realitas Baru dan Orientasi Masa Depan Bangsa, (Jakarta: UI-Press, 1993

Munawir Sjadzali, Muslim's Interest are Better Served in the Absence of Muslim Parties (Jakarta: Departemen Agama, 1992

Nurchalis Madjid, et. al., Pembaharuan Pemikiran Islam, (Jakarta: Islamic Research Center, 1970

Nurchalis Madjid, Islam, Kemerdekaan dan Keindonesiaan, (Bandung: Mizan, 1987

Sayyid Husein Nasr, Muhammad: Man of Allah, (London: Muhammadi Trust, 1982

${ }^{1}$ Bakhtiar Efendi, Islam dan Negara: Transformasi dan praktik Politik Islam di Indonesia, (Jakarta: Paramadina, 1998), hlm. 126.

2Ibid., hlm. 125;Leonard Binder, "Islamic Tradition and Politics: The Kijaji and the Alim", A Commentary to Clifford Geertz's "The Javanese Kijaji: The Changing Role of A Cultural Broker", Comparative Studies in Society and History, Vol. 2, Oktober 1959-July 1960, hlm. 256.

${ }^{3}$ C.A.O. Van Nieuwenhuijze, "Islam and National Self-Realization in Indonesia," dalam Cross-Cultural Studies, (The Hague: Monton and Co., 1963), hlm. 136-156.

${ }^{4}$ Bakhtiar Efendi, op. cit., hlm. 23-48

${ }^{5}$ Munawir Sjadzali lahir di desa Karanganom, Klaten, Jawa Tengah, pada 7 November 1925. Munawir Sjadzali adalah anak tertua dari delapan bersaudara dari pasangan Abu Aswad Hasan Sjadzali (putra Tohari) dan Tas'iyah (putrid Badruddin). Setelah menikah, sesuai dengan tradisi di desa Karanganom, ayah Munawir Sjadzali mendapat nama tua Mughaffir. Setelah menamatkan Sekolah Menengah Pertama/Tinggi Islam "Mambaul Ulum" di 
Kholil Syu'aib, Agama dan Negara...

Solo, menjadi guru di Ungaran, Semarang. Selama masa perjuangan kemerdekaan ikut menyumbangkan tenaga antara lain sebagai penghubung antara Markas Pertempuran Jawa Tengah dengan badan-badan kelaskaran Islam. Kariernya di lingkungan Depatemen Luar Negeri dirintisnya sejak tahun 1950 ketika ditugaskan pada Seksi Arab/Timur Tengah. Munawir Sjadzali merupakan tokoh intelektual dan agama serta diplomat yang menjabat sebagai Menteri Agama sejak Kabinet Pembangunan IV (1983-1988). Riwayat hidup Munawir selengkapnya dapat dilihat pada buku "Dari Lembah Kemiskinan," dalam Kontekstualisasi Ajaran Islam: 70 Tahun Prof. Dr. H. Munawir Sjadzali, MA, (Jakarta: Yayasan Paramadina, 1995): Munawir Sjadzali, Islam Realitas Baru dan Orientasi Masa Depan Bangsa, (Jakarta: UI-Press, 1993), sampul belakang.

${ }^{6}$ Munawir Sjadzali, Islam dan Tata Negara, (Jakarta: UI Press, 1993), hlm. 12 .

${ }^{7}$ Muhammad Din Syamsuddin, Etika Agama dalam Membangun Masyarakat Madani, (Jakarta: Logos, 2000), hlm. 58.

8Ibid.

${ }^{9}$ Nurchalis Madjid, Islam, Kemerdekaan dan Keindonesiaan, (Bandung: Mizan, 1987), hlm. 253-256.

${ }^{10}$ Nurchalis Madjid, et. al., Pembaharuan Pemikiran Islam, (Jakarta: Islamic Research Center, 1970), hlm. 4.

11Ibid.

12Ibid.

${ }^{13}$ Azyumardi Azra, dan Saiful Umam, (ed.), Menteri-Menteri Agama RI Biografi Sosial-Politik, (Jakarta: PPIM, 1998), hlm. 372

${ }^{14}$ Munawir, op. cit., hlm. 21-28.

15Sayyid Husein Nasr, Muhammad: Man of Allah, (London: Muhammadi Trust, 1982), hlm. 33.

16Ibid.

17Munawir, op. cit., hlm. 8-20

${ }^{18}$ Ahmad Syafii Maarif, "Piagam Madinah dan Konfergensi Sosial" apendiks dalam Islam dan Politik Pada Masa Demokrasi Terpimpin (1959-1965, (Yogyakarta: IAIN Sunan Kalijaga Press, 1988), hlm. 149-163.

${ }^{19}$ Munawir, op. cit., hlm. 16

${ }^{20}$ Ibid., hlm. 235.

${ }^{21}$ Munawir Sjadzali, op. cit., hlm. 189-198.

${ }^{22}$ Harry J. Benda, The Cresent and the Rising Sun: Indonesian Islamunder the Japanese Occupation 1942-1945 (The Hague and Bandung: W. van Hoeve Ltd., 1958) 
Kholil Syu'aib, Agama dan Negara...

${ }^{23}$ Bahtiar Effendi, "Islam and the State in Indonesia: Munawir Sjadzali and the Development of New Theological Underpinning of Political Islam," Studia Islamika, Volume 2, Number 2, 1995, hlm. 106-7

${ }^{24}$ Munawir Sjadzali, op. cit., hlm. 199

${ }^{25} \mathrm{Ibid} ., \mathrm{hlm} .210$.

${ }^{26}$ Azyumardi Azra, op. cit., hlm. 389.

${ }^{27}$ Azyumardi Azra, op. cit., hlm. 389.

${ }^{28}$ Ibid., hlm. 390.

29Ibid., hlm. 391; Kompas, 22 April 1982

${ }^{30}$ Faisal Ismail, "Pancasila as a Sole Basis for All Political Parties and for All Mass Organizations: An Account of Muslims Responses, "Studia Islamika, Volume 3, Number 4, 1996

${ }^{31}$ Tentang Tugas pokok ini diakui Munawir Sjadzali dalam "Dari Lembah Kemiskinan", op. cit., hlm. 78

32Ibid. Wawancara Munawir Sjadzali, Jakarta 6 Septemebr 1991, prinsip tersebut dikemukakan Presiden dalam Pidato 16 Agustus 1986

${ }^{33}$ Azyumardi Azra, op. cit., hlm. 396

${ }^{34}$ Munawir Sjadzali, loc. cit.; Panji Masyarakat, No. 404, 11 Juni 1985

${ }^{35}$ Hasbullah Mursyid, "Menelusuri Faktor Sosial yang Mungkin Berpengaruh, "dalam Kontekstualisasi Ajaran Islam, 70 Tahun Munawir Sjadzali, hlm. 202

36Munawir Sjadzali, op. cit., hlm. 4-8.

37Suara Karya, 21 Maret 1984

${ }^{38}$ Munawir Sjadzali, op. cit., hlm. 236; Secara eksplisit Munawir mengungkapkan konsep ini pada acara Dies Natalis HMI ke-43 dalam makalah "Wawasan Perjuangan Muslim Indonesia", Yogyakarta, 4 Pebruari 1990; Konsep ini sebenarnya berasal dari NU. Dalam muktamar ke-27, organisasi ini mendeklarasikan bahwa negara Indonesia merupakan tujuan final masyarakat Islam Indonesia. "Pimpinan PBNU bertemu Presiden: Negara RI adalah bentuk Final", Kompas, 15 Pebruari 1985

${ }^{39}$ Deliar Noer, Islam dan Pemikiran Politik: Bahasan Kitab Islam dan Tata Negara oleh H. Munawir Sjadzali, MA (Jakarta: LIPPM, 1990), hlm. 20-21 ${ }^{40}$ Deliar Noer, Islam, Pancasila, dan Asas Tunggal (Jakarta: Yayasan Perkhidmatan, 1984)

${ }^{41}$ Faisal Ismail, "Pancasila as a Sole Basis", op. cit., hlm.57-59

${ }^{42}$ Einar Martahan Sitompul, NU dan Pancasila (Jakarta: Sinar Harapan, 1989)

${ }^{43}$ Ibid.

Al-Fikra: Jurnal Ilmiah Keislaman, Vol. 3, no.1, Januari-Juni 2004 
Kholil Syu'aib, Agama dan Negara...

${ }^{44}$ Lukman Harun, Muhammadiyah dan Asas Pancasila (Jakarta: Pustaka Panjimas, 1986); Faisal Ismail, "Pancasila as a Sole Basis", op. cit., hlm. 59.

${ }^{45}$ Faisal Ismail, "Pncasila as a Sole Basis," hlm. 39

46Munawir Sjadzali, Muslim's Interest are Better Served in the Absence of Muslim Parties (Jakarta: Departemen Agama, 1992), hml. 9-10

47Munawir Sjadzali, Islam dan Tata Negara, op. cit., hlm. 236. 